\title{
Response of Several Cultivars of Maize (Zea mays L.) to Different Plant Density
}

\section{Sinan A.A. Al-Salmani, A.A. Almarie and Z.A. Abdulhamed}

Dept. of Field Crops - Coll. of Agric. Univ. of Anbar. Iraq.

Correspondence Author: Sinan A.A. Al-Salmani, Dept. of Field Crops - Coll. of Agric. Univ. of Anbar. Iraq.

Received date: 11 April 2018, Accepted date: 15 June 2018, Online, Online date: 25 June 2018

Copyright: (C) 2018 Sinan A.A. Al-Salmani et al. This is an open-access article distributed under the terms of the Creative Commons Attribution License, which permits unrestricted use, distribution, and reproduction in any medium, provided the original author and source are cre dited.

\begin{abstract}
Factorial experiment was conducted during the spring and fall seasons 2015 at the research station of experimental farm of Field Crop Sciences, in the alternative location of college of agriculture, $33^{\circ} 17^{\prime} 30^{\prime \prime} \mathrm{N} 44^{\circ} 3^{\prime} 56^{\prime \prime} \mathrm{E}$ in Abu-Ghraib, University of Alanbar, the study aimed to investigate response of four maize cultivars (buhooth 106, 5012, 5015, 5018) to four plant density $(53.3,60.6,70.1,83.3)$ thousand plant.ha-1. Randomized complete block design (RCBD) was used with three replicates, the plant density was significantly affected in all vegetative growth characters, the plant density of 83.3 thousand plants .ha ${ }^{-1}$ gave the highest values in crop growth rate 12.30 and 21.52 gm $^{-2}$.day ${ }^{-1}$, leaf area index 3.44 and 3.89 and seed yield 10.08 and 12.35 ton.ha-1 in both two seasons respectively, while the plant density of 53.3 thousand plants .ha- 1 gave the highest values in laves area 0.447 and $0.525 \mathrm{~m} 2$.plant ${ }^{-1}$, number of seeds rows in the ear 15.82 and 16.75 rows and the weight of 300 seeds 88.0 and $90.73 \mathrm{gm}$ in both seasons respectively. The cultivars differed significantly in most of the studied characters, the cultivar 5018 gave the highest seed yield 9.87 ton. ha-1 in the spring season with an increase in yield from 8.19 ton. ha ${ }^{-1}$ in lowest plant density to 10.08 ton. ha-1 in highest plant density 83.3 thousand plant. ha-1, while the two cultivars of (buhooth 106 and 5012) gave the highest seeds yield 11.74 and 11.46 ton.ha-1 respectively. Yield area unit (hectare) increased from 10.24 to 12.35 ton.ha $^{-1}$ in fall season, The effect of the interaction between the two factors of the study was significant in most of the characters in both seasons, the interaction treatment (plant density 83.3 thousand plants.ha ${ }^{-1} \times$ cultivar 5018) gave the highest average of seeds yield in the spring season, while in the fall season the interaction treatment (plant density 83.3 thousand plants ha $^{-1} \times$ cultivar of buhooth 106) gave the highest average of crop growth rate and seeds yield. According to the results of this research, we recommend using cultivars buhooth 106 and 5018 with high plant density in spring season, also using 106 cultivars with high plant density in the fall season.
\end{abstract}

Key words: Peanut, potassium, calcium, planting dates, pod yield.

\section{INTRODUCTION}

The maize (Zea mays L.) is one of the most important cereal crops grown in large areas to solve the problem of global food crisis, it is ranked third in terms of economic importance after wheat and rice crops, and its importance is derived from its use as a food, feed and oil crop and has recently been used as a biofuel, the global average production of maize crop 5.18 ton.ha $^{-1}$ with a cultivated area reached 170.40 million hectares, while in Iraq, the production of maize crop is low compared to global production which reached 2.6 ton.ha $^{-1}$, with total cultivated area estimated 128736 hectares [1], this may be due to the lack of use of highproductivity and adapted genotypes to the local environment, and poor soil and crop service operations, the good field management contributes by $30-50 \%$, while genetic improvement contributes to the remaining percentage in yield of this crop [2].

The yield increase is due to breeding and improvement programs and to understand the interaction between genetics effect and field operations, it is important to test genotypes under crop management and plants densities [3]. The cultivar is not the only factor that leads to achieving the highest productivity, but there are other factors, including plant density, which is important factor in the concept of field management, also the form of relationship between vegetation growth and the yield depends on this management so must choose the plant density which can intercept (95\%) of solar radiation, which is positively reflected by increase of plant growth and its branches and the increase in economic and biological yield, the plant density is one of the most important agricultural operations that affect in seeds yield, the increase of plant density with other conditions suitable for growth to increase of the seeds yield to reach the optimal plant density, which gives the highest yield of the seeds, the seeds yield is the most important field parameter of the genotype, the seeds yield is the most important field criterion of genotype, also it is the end result of the biological activities of the plant which related mainly with the genetic factor and its interaction with the available growth factors[4].

The superiority of cultivar in seed yield indicates to its high efficiency in the exploitation of environmental factors to increase the process of Photosynthesis then transform the products of Photosynthesis into an economic yield [5]. The research aims to determine the best plant density to obtain the highest yield and determine the best cultivar, which suitable for environmental conditions in the region and gives the highest yield, finally, to find the best interaction between the plant density and cultivars to obtain the highest productivity.

\section{MATERIALS AND METHODS}

In this study, four cultivars of maize (buhooth 106, 5012, 5015 and 5018) and four plant densities were used, the distance between the lines was $0.75 \mathrm{~m}$ in all treatments, the change in plant density was based on changing the distance between the holes so that is $0.75 \times 0.25,0.75 \times 0.21,0.75 \times 0.19$ and $0.75 \times 0.16$ gave plants densities 53333, 60606, 70175 and 83333 plant.ha $^{-1}$, the experimental treatments are distributed according to factorial experiment arrangement using completely randomized blocks with three replicates. 
The study was carried out in the fields of college of agriculture-Anbar University in Abu Ghraib (alternative location) for two seasons (spring and autumn) 2015, in each season, the soil of the experiment was prepared, Tillage, pulverization, and leveling were carried out and split the experiment field according to scientific recommendations, Urea fertilizer $(46 \% \mathrm{~N})$ was added in a quantity of $200 \mathrm{~kg} \cdot \mathrm{ha}^{-1}$, the weeds were controlled by using Atarazine pesticide $(80 \%$ active ingredient) with $1 \mathrm{~kg} \cdot \mathrm{ha}^{-1}$ after planting and before germination, the manual weeding continued according to the need of the experiment, the corn stalk borer, (Sesamia cretica. L) was controlled by using Diazinon (10\% active ingredient) with $6 \mathrm{~kg}^{-h^{-1}}$, the insecticide added in two doses first (preventive) when reaching the height of the plant $20 \mathrm{~cm}$ and the second one applied after two weeks of the first addition.

Studied characters:

1- The duration of female flowering until silking in $50 \%$ of plants cultivars in a treatment unit.

2- The average of plant height $(\mathrm{cm})$ of the ten protected plants from the soil surface to the base of the tassel.

3- The average of total leaf area of the plant $\left(\mathrm{m}^{2}\right)$ in milky stage according to the equation:

The leaf area of plant $=$ squared length of the leaf located directly below ear leaf $\times 0.75[6]$.

4- Leaf area index.

5- Crop growth rate $\left(\mathrm{gm} \cdot \mathrm{m}^{2}\right.$.day $\left.{ }^{-1}\right)$ : extracted from the total dry matter of the plant divided by the number of days from germination to physiological maturity.

$$
\mathrm{CGR}=\frac{\text { total dry matter of the plant }}{\text { the }}
$$

$$
\mathrm{CGR}=\frac{\text { total dry matter of the plant }}{\text { number of days from germination to physiological maturity }}
$$

6- The number of rows per ear.

7- The number of seeds per row

8- Weight of 300 seeds (gm) with $15.5 \%$ moisture [6].

9-Seeds yield (ton.ha ${ }^{-1}$ ) : Ten plants from each experimental unit were harvested randomly from the protected medium lines then calculated by multiplying the average of seeds yield of one plant and on the basis of the plant density, it was converted to (ton.ha ${ }^{-1}$ ).

\section{Statistical analysis:}

Statistical analyses were performed using the randomized complete block design (RCBD) with three replicates, according to [7]. Mean values of the characters were tested using the least significant difference at the significance level $5 \%$.

\section{RESULTS AND DISCUSSION}

Silking:

The results of Table 1, showed the significant differences among cultivars, densities and interaction between plant cultivars and densities in silking under the two growing seasons, but the interaction of the spring season was not significant, the lowest duration of silking was 69.25 and 59.52 days which obtained from cultivar 5012 in each of spring and fall seasons respectively, the highest duration of silking was 70.65 and 60.70 days which obtained from cultivar 5015 in each of spring and fall seasons respectively. the low plant density (53.3 thousand plant.ha $\left.{ }^{-1}\right)$ gave the lowest number of days until silking reached 69.0 and 58.42 days in each of spring and fall seasons respectively, but in the spring season did not differ significantly with the density of (60.6 and 70.1 thousand plant.ha $\left.{ }^{-1}\right)$, the high plant density ( 83.3 thousand plant.ha ${ }^{-1}$ ) gave the highest duration of silking 70.35 and 62.00 days in each of spring and fall seasons respectively, the increase the plant density leads to increase of days number from planting to silking and lead to the continuation of vegetative growth due to increased shadow, which reduces the temperature of soil near the plant (plant environment).

\begin{tabular}{|c|c|c|c|c|c|c|c|c|c|c|}
\hline \multirow[t]{3}{*}{ Cltivars } & \multicolumn{5}{|c|}{ Spring season } & \multicolumn{5}{|c|}{ Fall season } \\
\hline & \multicolumn{4}{|c|}{ Plants density plant.ha ${ }^{-1}$} & \multirow[t]{2}{*}{ Mean } & \multicolumn{4}{|c|}{ Plants density plant.ha ${ }^{-1}$} & \multirow[t]{2}{*}{ Mean } \\
\hline & 53.3 & 60.6 & 70.1 & 83.3 & & 53.3 & 60.6 & 70.1 & & \\
\hline Buhooth 106 & 69 & 68.80 & 69.70 & 69.90 & 69.35 & 58.50 & 58.90 & 60.10 & 61.80 & 59.82 \\
\hline 5012 & 68.80 & 68.80 & 69.00 & 70.40 & 69.25 & 56.80 & 59.20 & 60.30 & 61.77 & 59.52 \\
\hline 5015 & 69.90 & 70.30 & 71.00 & 71.40 & 70.65 & 60.00 & 59.80 & 60.30 & 62.71 & 60.70 \\
\hline 5018 & 68.30 & 68.90 & 69.10 & 70.77 & 69.30 & 58.40 & 59.50 & 60.80 & 61.70 & 60.10 \\
\hline Mean & 69.00 & 69.20 & 69.45 & 70.35 & & 58.42 & 59.31 & 60.37 & 62.00 & \\
\hline L.S.D 5\% & \multicolumn{4}{|l|}{0.96} & 0.96 & \multicolumn{4}{|l|}{0.63} & 0.63 \\
\hline L.S.D 5\% & \multicolumn{5}{|l|}{ N.S } & \multicolumn{5}{|l|}{1.26} \\
\hline
\end{tabular}

Table 1: The number of days from planting to $50 \%$ silking of maize under effect of cultivars and four levels of plant density in the spring and fall seasons of 2015

These results in agreement with results of [6], which indicates that doubling the plant density from 35 to 70 thousand plant.ha ${ }^{-1}$ leads to increase of duration of the plant growth with average 2-3 days due to the lack of light acquisition by the plant and the reduction of photosynthesis products, the interaction effect between plant cultivars and densities was not significant in spring season, while it was significant in the fall season, the cultivar 5012 take the lowest time to reach the silking 56.80 days with The low density while the cultivar 5015 take the longest period of silking 62.71 days with high density ( by $9.4 \%$ decrease in number of days). These results in agreement with results of [8] that increased of plant density lead to delayed silking and they indicate the important role of genetic factors in synchronizing of silking.

\section{Plant height $(\mathrm{cm})$ :}

In determinate growth plants such as maize, plant height is determined by the appearance of tassel and the dispersion of pollen grains which affected by genotype and growth factors, the results of Table 2 showed the cultivar 5012 gave the highest values of plant height reached 184.34 and $181.18 \mathrm{~cm}$ in spring and fall seasons respectively, while cultivar 5015 gave the lowest values 165.65 and $172.25 \mathrm{~cm}$ respectively in the spring and fall seasons respectively, the increase in plant density from 53.3 to 83.3 leads to increase of plant height by $3.6 \%$ and $4.3 \%$ in each of spring and fall seasons, the increase in plant height leads to shading and elongation of internodes, these are in agreement with results of [9], who confirmed that the increase of plant density leads to increase in the height of the plant until the plant density of 100 thousand plant.ha ${ }^{-1}$ then the increase stops due to decrease photosynthesis resulting from lack of light, the effect of interaction

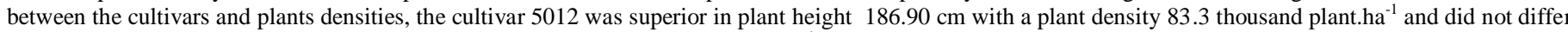
significantly with the same cultivar with the plant density 70.1 thousand plants. ha $^{-1}$ in the spring season, the reason is that plant density leads to decrease of light, therefore the level of Auxin in the stem will increase to a higher level and this leads to an increase in plant height [10], in the fall season, the effect of interaction was not significant.

\section{Leaf area:}

Most of photosynthesis and carbon production occur in plant leaves, Therefore, the measurement of leaf area is one of great importance in determining the productive potential of cultivars, The competition between plants for light, water and other growth requirements is an important factor in the leaf area average [11], the results of Table 3 indicate that cultivar 5018 gave the highest leaf area $0.444 \mathrm{~m} 2$ and did not differ significantly with cultivar of buhooth 106 in spring season, while in fall season, the cultivar 5012 gave the highest leaf area $0.517 \mathrm{~m} 2$ and did not differ significantly with cultivar of buhooth 106 , but the cultivar 5018 gave the lowest value of the same character in the same season, the low plant density 53.3 thousand plant.ha ${ }^{-1}$ was superior in the leaf area in spring and fall seasons by $2.7 \%, 8.5 \%$ and $9.8 \%$ compared to cultivated cultivars with $60.6,70.1$ and 83.3 thousand plant.ha ${ }^{-1}$ in the spring season respectively, and by $1.9 \%$, $6.9 \%$ and $14.9 \%$ in the fall season respectively, the increase in plant density leads to decrease the number of leaves because of competition for light, water and nutrients, the interaction treatment of cultivar 5018 with plant density 53.3 thousand plants ha $^{-1}$ gave the highest value in this character and it did not differ significantly with the 
Citation: Sinan A.A. Al-Salmani et al., 2018. Response of Several Cultivars of Maize (Zea mays L.) to Different Plant Density. Advances in Environmental Biology., 12(6): 9-13.

cultivar of buhooth 106 while the lowest value of this character obtained from cultivar 5012 with high density 83.3 thousand plant.ha ${ }^{-1}$ in the spring season, while in fall season there are no significant differences in interaction treatments.

Table 2: plant height $(\mathrm{cm})$ of maize under effect of cultivars and four levels of plant density in the spring and fall seasons of 2015.

\begin{tabular}{|c|c|c|c|c|c|c|c|c|c|c|}
\hline \multirow[t]{3}{*}{ Cultivars } & \multicolumn{5}{|c|}{ Spring season } & \multicolumn{5}{|c|}{ Fall season } \\
\hline & \multicolumn{4}{|c|}{ Plants density plant.ha ${ }^{-1}$} & \multirow[t]{2}{*}{ Mean } & \multicolumn{4}{|c|}{ Plants density plant.ha ${ }^{-1}$} & \multirow[t]{2}{*}{ Mean } \\
\hline & 53.3 & 60.6 & 70.1 & 83.3 & & 53.3 & 60.6 & 70.1 & 83.3 & \\
\hline Buhooth 106 & 163.10 & 164.00 & 167.21 & 170.00 & 166.07 & 170.40 & 171.30 & 175.10 & 176.50 & 173.32 \\
\hline 5012 & 182.10 & 183.90 & 184.80 & 186.90 & 184.34 & 175.50 & 180.60 & 183.50 & 185.10 & 181.18 \\
\hline 5015 & 162.20 & 162.30 & 166.80 & 171.30 & 165.65 & 168.20 & 169.40 & 174.30 & 177.10 & 172.25 \\
\hline 5018 & 170.10 & 171.30 & 172.40 & 174.00 & 171.95 & 174.20 & 173.60 & 176.50 & 178.90 & 175.57 \\
\hline Mean & 169.37 & 170.37 & 172.80 & 175.55 & & 172.07 & 173.72 & 177.35 & 179.40 & \\
\hline L.S.D 5\% & \multicolumn{4}{|l|}{1.19} & 1.19 & \multicolumn{4}{|l|}{1.75} & 1.75 \\
\hline L.S.D 5\% & \multicolumn{5}{|l|}{2.37} & \multicolumn{4}{|l|}{ N.S } & \\
\hline
\end{tabular}

Table 3: leaf area of maize under effect of cultivars and four levels of plant density in the spring and fall seasons of 2015.

\begin{tabular}{|c|c|c|c|c|c|c|c|c|c|c|}
\hline \multirow[t]{3}{*}{ Cultivars } & \multicolumn{5}{|c|}{ Spring season } & \multicolumn{5}{|c|}{ Fall season } \\
\hline & \multicolumn{4}{|c|}{ Plants density plant.ha $^{-1}$} & \multirow[t]{2}{*}{ Mean } & \multicolumn{4}{|c|}{ Plants density plant.ha $^{-1}$} & \multirow[t]{2}{*}{ mean } \\
\hline & 53.1 & 60.6 & 70.1 & 83.3 & & 53.1 & 60.6 & 70.1 & 83.3 & \\
\hline Buhooth 106 & 0.465 & 0.435 & 0.421 & 0.419 & 0.436 & 0.533 & 0.525 & 0.510 & 0.489 & 0.514 \\
\hline 5012 & 0.434 & 0.423 & 0.405 & 0.389 & 0.413 & 0.547 & 0.536 & 0.507 & 0.480 & 0.517 \\
\hline 5015 & 0.419 & 0.420 & 0.427 & 0.403 & 0.417 & 0.530 & 0.516 & 0.499 & 0.469 & 0.503 \\
\hline 5018 & 0.470 & 0.458 & 0.433 & 0.418 & 0.444 & 0.491 & 0.483 & 0.451 & 0.432 & 0.464 \\
\hline Mean & 0.447 & 0.435 & 0.412 & 0.407 & & 0.525 & 0.515 & 0.491 & 0.457 & \\
\hline L.S.D 5\% & 0.013 & & & & 0.013 & 0.009 & & & & 0.009 \\
\hline L.S.D 5\% & 0.022 & & & & & N.S & & & & \\
\hline
\end{tabular}

\section{Leaf area index:}

The results of Table 4 indicate that cultivar 5018 was superior in the highest leaf area index reached 2.93 and did not differ significantly with the cultivar of buhooth 106 in the spring season, while in fall season, the cultivar 5012 gave the highest leaf area index 3.42 and did not differ significantly with the cultivar of buhooth 106, while the cultivar 5018 gave the lowest value 3.08 of leaf area index in the same season, the increase in plant density leads to an increase in the leaf area index.

Table 4: Leaf area index of maize under effect of cultivars and four levels of plant density in the spring and fall seasons of 2015.

\begin{tabular}{|c|c|c|c|c|c|c|c|c|c|c|}
\hline \multirow[t]{3}{*}{ Cultivars } & \multicolumn{5}{|c|}{ Spring season } & \multicolumn{5}{|c|}{ Fall season } \\
\hline & \multicolumn{4}{|c|}{ Plants density plant.ha ${ }^{-1}$} & \multirow[t]{2}{*}{ Mean } & \multicolumn{4}{|c|}{ Plants density plant.ha $^{-1}$} & \multirow[t]{2}{*}{ Mean } \\
\hline & 53.3 & 60.6 & 70.1 & 83.3 & & 53.3 & 60.6 & 70.1 & 83.3 & \\
\hline Buhooth 106 & 2.48 & 2.72 & 2.95 & 3.49 & 2.91 & 2.84 & 3.18 & 3.58 & 4.07 & 3.41 \\
\hline 5012 & 2.31 & 2.56 & 2.84 & 3.24 & 2.73 & 2.91 & 3.25 & 3.55 & 4.00 & 3.42 \\
\hline 5015 & 2.23 & 2.54 & 2.99 & 3.58 & 2.83 & 2.82 & 3.12 & 3.50 & 3.91 & 3.33 \\
\hline 5018 & 2.50 & 2.77 & 3.04 & 3.48 & 2.93 & 2.62 & 3.92 & 3.16 & 3.60 & 3.08 \\
\hline Mean & 2.38 & 2.64 & 2.95 & 3.44 & & 2.79 & 3.11 & 3.44 & 3.89 & \\
\hline L.S.D 5\% & \multicolumn{4}{|c|}{0.059} & 0.059 & \multicolumn{4}{|c|}{0.073} & 0.035 \\
\hline L.S.D 5\% & \multicolumn{5}{|c|}{0.118} & \multicolumn{4}{|l|}{ N.S } & \\
\hline
\end{tabular}

The plant density 83.3 thousand plant.ha ${ }^{-1}$ gave the highest leaf area index 3.44 and 3.89 in the spring and fall seasons respectively, the increase in the leaf area index of high plant density 83.3 thousand plants. ha $^{-1}$ reached $16.6 \%, 30 \%$ and $44.5 \%$ in treatments of plant densities $70.1,60.6,53.3$ thousand plants .ha ${ }^{-1}$ in spring season respectively, $13 \%, 25 \%$, and $39.4 \%$ respectively in the fall season, increasing the plant density leads to increase the leaf area index due to the lack of distance between plants and thus increase the collection of sunlight by the leaves of maize in the high densities, the response of the cultivars of this characters were significant different according to differences among densities of the plant, the highest leaf area index was in the highest plant density 83.3 thousand plant.ha ${ }^{-1}$ obtained from cultivar 5015 which reached 3.58 with an increase by $60.5 \%$ compared to the same cultivar in the lowest plant density 53.3 thousand plant.ha ${ }^{-1}$, while in fall season, there are no significant differences.

\section{Crop growth rate:}

The crop growth rate is the increase in plant dry weight per area unit in the time unit and expressed in units $\left(\mathrm{gm}-\mathrm{m}^{2} \mathrm{day}^{-1}\right)$, the increase of the plant dry matter in the area unit depends on the growth rate and its period, and this is related to the nature of the genetic effect and the available growth factors, the crop growth rate is slightly in the early stages of plant growth because of the lack of vegetation cover and the collecting of a small percentage of sunlight then increase rapidly with the age increase of the plant, the results of Table 5indicate that the cultivar 5012 gave the highest plant growth rate per square meter and did not differ significantly with cultivar of buhooth 106 in the spring season, while in the fall season, the cultivar of buhooth 106 achieved the highest value in plant growth rate 20.65 $\mathrm{gm} . \mathrm{m}^{2}$. day ${ }^{-1}$, the lowest rate of the character was $17.70 \mathrm{gm} . \mathrm{m}^{2}$.day ${ }^{-1}$ obtained from cultivar 5015, the increase of plant density leads to increase of plant growth rate per square meter by $6.6 \%, 12.4 \%$ and $19.18 \%$ with densities $60.6,70.1$ and 83.3 thousand plants .ha ${ }^{-1}$ in spring season respectively, and $9.63 \%, 17.87$ and 25.7 in fall season respectively, with plant density 53.3 thousand plants .ha ${ }^{-1}$,the increase of plant density leads to an increase in plant growth rate in cultivated area unit due to high plant density, these results in agreement with results of $[8,11]$, the interaction was insignificant in the spring season, while in the autumn season, the interaction treatment of buhooth 106 cultivar with high density 83.3 thousand plant.ha ${ }^{-1}$ gave the highest rate of this character reached 23 gm.m $^{2}$. day $^{-1}$ and the lowest growth rate obtained from interaction treatment of low plant density 53.3 thousand plants .ha ${ }^{-1}$ with cultivar of 5015 which reached $15.8 \mathrm{gm} . \mathrm{m}^{2}$. day ${ }^{1}$ ( with an increase by $45.6 \%$ ).

\section{Number of rows per ear:}

When the size of the ear is determined, the number of rows in it is determined genetic environmental factors affect in this character, and it is a secondary component, which has a high inheritance, however, the lack of photosynthesis products is lead to failure of the development of total flowers in one or more rows in the ear [11]. The results of Table 6 show the superiority of cultivar 5012 by giving the highest number of rows per ear reached 16.91 rows in the spring season, while in the fall season the cultivar of buhooth 106 gave the highest value 17.15 rows, but the lowest value of rows per ear obtained from cultivar of 5015 which gave 14.42 and $15.11 \mathrm{~cm}$ in each of spring and fall seasons respectively, as for the density of the plant, the low density 53.3 thousand plant.ha ${ }^{-1}$ was superior with an increase by $2 \%$ and $3.4 \%$ compared to the plant densities 70.1 and 83.3 thousand plants .ha ${ }^{-1}$ respectively in the spring season and $3.7 \%$ and $6.5 \%$ respectively in the fall season, while the plant density 53.3 did not differ significantly from plant density 60.6 thousand plants .ha ${ }^{-1}$ in the spring and fall seasons. 
Citation: Sinan A.A. Al-Salmani et al., 2018. Response of Several Cultivars of Maize (Zea mays L.) to Different Plant Density. Advances in Environmental Biology., 12(6): 9-13.

Table 5: Plant growth rate of maize under effect of cultivars and four levels of plant density in the spring and fall seasons of 2015.

\begin{tabular}{|c|c|c|c|c|c|c|c|c|c|c|}
\hline \multirow[t]{3}{*}{ Cultivars } & \multicolumn{5}{|c|}{ Spring season } & \multicolumn{5}{|c|}{ Fall season } \\
\hline & \multicolumn{4}{|c|}{ Plants density plant.ha ${ }^{-1}$} & \multirow[t]{2}{*}{ Mean } & \multicolumn{4}{|c|}{ Plants density plant.ha $^{-1}$} & \multirow[t]{2}{*}{ Mean } \\
\hline & 53.3 & 60.6 & 70.1 & 83.3 & & 53.3 & 60.6 & 70.1 & 83.3 & \\
\hline Buhooth 106 & 10.5 & 11.3 & 12.0 & 12.7 & 11.62 & 18.2 & 20.0 & 21.5 & 23.0 & 20.65 \\
\hline 5012 & 10.7 & 11.4 & 11.9 & 12.6 & 11.67 & 18.0 & 19.7 & 21.1 & 22.8 & 20.40 \\
\hline 5015 & 10.3 & 11.0 & 11.6 & 12.2 & 11.27 & 15.8 & 17.4 & 18.5 & 19.3 & 17.70 \\
\hline 5018 & 9.8 & 10.3 & 10.9 & 11.6 & 10.68 & 16.6 & 18.0 & 19.8 & 21.0 & 18.85 \\
\hline Mean & 10.32 & 11.00 & 11.60 & 12.30 & & 17.12 & 18.77 & 20.18 & 21.52 & \\
\hline L.S.D 5\% & \multicolumn{4}{|l|}{0.17} & 0.17 & \multicolumn{4}{|l|}{0.22} & 0.22 \\
\hline L.S.D 5\% & \multicolumn{5}{|l|}{ N.S } & \multicolumn{4}{|l|}{0.45} & \\
\hline
\end{tabular}

Table 6: Number of rows per ear of maize under effect of cultivars and four levels of plant density in the spring and fall seasons of 20.

\begin{tabular}{|c|c|c|c|c|c|c|c|c|c|c|}
\hline \multirow[t]{3}{*}{ Cultivars } & \multicolumn{5}{|c|}{ Spring season } & \multicolumn{5}{|c|}{ Fall season } \\
\hline & \multicolumn{4}{|c|}{ Plants density plant.ha ${ }^{-1}$} & \multirow[t]{2}{*}{ Mean } & \multicolumn{4}{|c|}{ Plants density plant.ha ${ }^{-1}$} & \multirow[t]{2}{*}{ Mean } \\
\hline & 53.3 & 60.6 & 70.1 & 83.3 & & 53.3 & 60.6 & 70.1 & 83.3 & \\
\hline Buhooth 106 & 15.50 & 15.13 & 15.00 & 14.80 & 15.10 & 17.70 & 17.60 & 16.95 & 16.37 & 17.15 \\
\hline 5012 & 17.00 & 17.00 & 17.00 & 16.60 & 16.91 & 17.10 & 17.00 & 16.75 & 16.53 & 16.84 \\
\hline 5015 & 14.70 & 14.80 & 14.20 & 14.00 & 14.42 & 15.30 & 15.40 & 14.96 & 14.80 & 15.11 \\
\hline 5018 & 16.10 & 16.00 & 15.90 & 15.80 & 15.92 & 16.90 & 16.20 & 15.90 & 15.20 & 16.55 \\
\hline Mean & 15.82 & 15.73 & 15.50 & 15.30 & & 16.75 & 16.72 & 16.14 & 15.72 & \\
\hline L.S.D 5\% & \multicolumn{4}{|l|}{0.26} & 0.26 & \multicolumn{4}{|l|}{0.168} & 0.168 \\
\hline L.S.D 5\% & \multicolumn{5}{|l|}{ N.S } & \multicolumn{4}{|l|}{0.336} & \\
\hline
\end{tabular}

The effect of interaction of the cultivars with the plant density was insignificant in the spring season, while in the fall season, the cultivar of buhooth 106 with the density of 53.3 gave the highest value 17.70 rows per ear with increase by $19.6 \%$ compared to interaction treatment of 5015 cultivar with highest plant density 83.3 thousand plant.ha ${ }^{-1}$ which gave the lowest value of this character, this result shows the importance of testing this cultivar under plant densities to explore their actual potential and to understand the interaction between genetics and field processes [6]. These results in agreement with results of [12].

\section{Number of grains per row:}

After determining the number of rows per ear, the number of ovules in each row, which is transformed into mature grains after pollination and fertilization, which is important character because it determines the number of grains per ear [13], Table 7 shows that the cultivar 5018 is superior in terms of the highest number of grains per row 35.72 grains, while the cultivar buhooth 106 gave the lowest average 28.72 in the spring season, in the fall season the cultivar 5012 gave the highest value 34.08 of this character and did not differ significantly with cultivar 5018, we note from the Table results that the low plant density 53.3 thousand plant.ha ${ }^{-1}$ which was significantly different with the other densities, with an increase of $2.8 \%, 7.4 \%$, and $13 \%$ compared to other plant densities $60.6,70.1$ and 83.3 thousand plants . ha ${ }^{-1}$ in spring season respectively, and by 3.9\%, $14.5 \%$ and $16.5 \%$ in fall season respectively, this result in agreement with results of [14,15,16]. The number of grains in the row with the effect of plant densities was significant. The cultivar 5018 gave the highest number of grains per row reached 39.13 in the spring season with an increase of $39.2 \%$. for the cultivar of buhooth 106 row which gave 37.41 grain per ear in the fall season with the plant density 83.3 thousand plant.ha ${ }^{-1}$, while the cultivar 5015 gave the highest number of grains per row reached 37.41in fall season with plant density 53.3 thousand plants .ha ${ }^{-1}$ with an increase of $35.6 \%$ for a cultivar of buhooth 106 with high plant density 83.3 thousand plant.ha ${ }^{-1}$.

Table 7: Number of grains per row of maize under the effect of cultivars and four levels of plant density in the spring and fall seasons of 2015 .

\begin{tabular}{|c|c|c|c|c|c|c|c|c|c|c|}
\hline \multirow[t]{3}{*}{ Cultivars } & \multicolumn{5}{|c|}{ Spring season } & \multicolumn{5}{|c|}{ Fall season } \\
\hline & \multicolumn{4}{|c|}{ Plants density plant.ha ${ }^{-1}$} & \multirow[t]{2}{*}{ Mean } & \multicolumn{4}{|c|}{ Plants density plant.ha $^{-1}$} & \multirow[t]{2}{*}{ Mean } \\
\hline & 53.3 & 60.6 & 70.1 & 83.3 & & 53.3 & 60.6 & 70.1 & 83.3 & \\
\hline Buhooth 106 & 29.37 & 29.3 & 29.16 & 28.11 & 28.98 & 32.74 & 31.33 & 27.37 & 27.58 & 29.75 \\
\hline 5012 & 33.72 & 32.27 & 32.28 & 30.91 & 32.30 & 35.15 & 34.93 & 29.97 & 30.19 & 32.56 \\
\hline 5015 & 35.71 & 35.90 & 32.70 & 30.22 & 33.63 & 37.41 & 35.57 & 32.67 & 30.66 & 34.08 \\
\hline 5018 & 39.13 & 36.67 & 34.31 & 32.78 & 35.72 & 35.01 & 33.15 & 33.10 & 31.96 & 33.16 \\
\hline Mean & 34.48 & 33.53 & 32.11 & 30.50 & & 35.7 & 33.74 & 30.63 & 30.9 & \\
\hline L.S.D 5\% & \multicolumn{4}{|l|}{0.88} & 0.88 & \multicolumn{4}{|l|}{1.11} & 1.11 \\
\hline L.S.D 5\% & \multicolumn{5}{|l|}{10.76} & \multicolumn{4}{|l|}{2.22} & \\
\hline
\end{tabular}

\section{Weight of 300 grains:}

The final grain weight is determined by the sink volume and the ability to extract the largest amount of metabolic outputs from the source which associated with the effectiveness of the leaves to photosynthesis [5], the grains also begin forming and filling rapidly after fertilization, the grain weight is one of the important factors of yield grains, which directly affect the grains yield of singular plant, the results of Table 8 show the superiority of the cultivar of buhooth 106 by giving the highest weight of 300 grains 93.46 and $99.18 \mathrm{gm}$ in the spring and fall seasons respectively, the cultivar 5012 gave the lowest value in the spring season, while in the fall season the cultivar 5018 gave the lowest value of this character, also the results of the same table shows that the plant density 53.3 thousand plant.ha ${ }^{-1}$ was superior compared to other densities with an increase by $1.9 \%, 5.2 \%, 10.7 \%$ for the densities $60.6,70.1$, and 83.3 thousand plants .ha ${ }^{-1}$ in spring season respectively, and by $0.8 \%$ and $3 \%$ and $5.2 \%$ in fall season respectively, the increase of plant density leads to the decrease of grain weight because of competition on photosynthesis products among tissues of the plant and the available growth factors among plants, which resulted in a decrease the number of endosperm cells and starchy grains such as the number of cells increased with increase of photosynthesis average and its products which is reflected on the weight of the grain [16], the same table indicates the difference in the response of the character with different of plant cultivars and densities, the best response of this character obtained from cultivar of buhooth 106 with plant density 53.3 thousand plant.ha ${ }^{-1}$ which gave the highest grain weight 97.80 and 100.30 gm in the spring and fall seasons respectively, while the lowest weight of the grain obtained from cultivar 5012 in the spring season, and cultivar 5018 in the fall season with plant density 83.3 thousand plant.ha ${ }^{-1}$ in the two seasons, These results in agreement with the results of $[17,18]$.

\section{Grain yield ton.ha $a^{-1}$ :}

The most important goal of plant breeders is increased the seeds yield in the area unit, this is based on the best standards to diagnosis of genotypes which characterized by the high grains yield as well as using of scientific agricultural operations, Table 9 shows that cultivar 5018 was superior compared to the others cultivars with the highest yield reached 9.87 ton.ha ${ }^{-1}$, while the cultivar 5015 gave the lowest seeds yield 8.55 ton.ha ${ }^{-1}$ in the spring season, while in the fall season the cultivar buhooth 106 gave the highest value of this character reached 11.74 ton.ha ${ }^{-1}$, the increase in plant density resulted in an increase by $9.4 \%, 12.9 \%$ and $26.4 \%$ for the densities of $60.6,70.1$ and 83.3 thousand plant.ha ${ }^{-1}$, in the spring season respectively, and $4.9 \%, 9.2 \%$ and $20.6 \%$ in fall season respectively, the plant density is one of the most important agricultural operations that effect on the grain yield and its increase with the a vailability of other suitable conditions for growth to increase the grain yield to reach the optimum density, which gives the highest average of grains productivity, this results in agreement with the results 
of $[6,19,20,21]$, who explained that the increase in plant density leads to an increase in grain yield per area unit, it is noted that the interaction treatment between the plant cultivars and plant densities were significantly, the cultivar 5018 gave the highest grains yield 10.33 ton.ha $^{-1}$ with high plant density 83.3 thousand plant.ha ${ }^{-1}$ with an increase of $32.26 \%$ from cultivar 5015 with density 53.3 thousand plants .ha ${ }^{-1}$ in the spring season, while in the fall season the cultivar of buhooth 106 achieved the highest grains yield reached 12.88 ton.ha ${ }^{-1}$ with the high plant density by an increase $39.5 \%$ from cultivar 5015 in the low density.

Table 8: Weight of 300 grains of maize under effect of cultivars and four levels of plant density in the spring and fall seasons of 2015.

\begin{tabular}{|c|c|c|c|c|c|c|c|c|c|c|}
\hline \multirow[t]{3}{*}{ Cultivars } & \multicolumn{5}{|c|}{ Spring season } & \multicolumn{5}{|c|}{ Fall season } \\
\hline & \multicolumn{4}{|c|}{ Plants density plant.ha ${ }^{-1}$} & \multirow[t]{2}{*}{ Mean } & \multicolumn{4}{|c|}{ Plants density plant.ha ${ }^{-1}$} & \multirow[t]{2}{*}{ Mean } \\
\hline & 53.3 & 60.6 & 70.1 & 83.3 & & 53.3 & 60.6 & 70.1 & 83.3 & \\
\hline Buhooth 106 & 97.80 & 94.67 & 94.00 & 87.40 & 93.46 & 100.30 & 100.00 & 99.60 & 96.80 & 99.18 \\
\hline 5012 & 76.30 & 77.10 & 70.70 & 70.00 & 73.52 & 82.90 & 82.80 & 82.00 & 80.14 & 81.96 \\
\hline 5015 & 90.30 & 88.60 & 86.40 & 80.60 & 86.47 & 93.90 & 93.92 & 91.90 & 90.04 & 92.44 \\
\hline 5018 & 87.60 & 85.00 & 83.30 & 79.90 & 83.95 & 85.80 & 83.30 & 78.90 & 77.77 & 81.44 \\
\hline Mean & 88.00 & 86.34 & 83.60 & 79.47 & & 90.73 & 90.00 & 88.10 & 86.18 & \\
\hline L.S.D 5\% & 1.23 & & & & 1.23 & 0.86 & & & & 0.86 \\
\hline L.S.D 5\% & 2.45 & & & & & 1.73 & & & & \\
\hline
\end{tabular}

Table 9: Grain yield ton.ha-1 of maize under the effect of cultivars and four levels of plant density in the spring and fall seasons of 2015.

\begin{tabular}{|c|c|c|c|c|c|c|c|c|c|c|}
\hline \multicolumn{6}{|l|}{ Spring season } & \multicolumn{5}{|c|}{ Fall season } \\
\hline \multirow[t]{2}{*}{ Cultivars } & \multicolumn{4}{|c|}{ Plants density plant.ha $^{-1}$} & \multirow[t]{2}{*}{ Mean } & \multicolumn{4}{|c|}{ Plants density plant.ha $^{-1}$} & \multirow[t]{2}{*}{ Mean } \\
\hline & 53.3 & 60.6 & 70.1 & 83.3 & & 53.3 & 60.6 & 70.1 & 83.3 & \\
\hline Buhooth 106 & 8.19 & 9.35 & 9.62 & 10.26 & 9.36 & 10.74 & 11.40 & 11.97 & 12.88 & 11.74 \\
\hline 5012 & 8.08 & 8.84 & 8.92 & 9.99 & 8.95 & 10.90 & 11.18 & 11.50 & 12.27 & 11.46 \\
\hline 5015 & 7.81 & 8.12 & 8.54 & 9.74 & 8.55 & 9.23 & 10.14 & 10.66 & 12.02 & 10.51 \\
\hline 5018 & 8.70 & 8.53 & 9.92 & 10.33 & 9.87 & 10.09 & 10.25 & 10.60 & 12.24 & 10.79 \\
\hline Mean & 8.19 & 8.96 & 9.25 & 10.08 & & 10.24 & 10.74 & 11.18 & 12.35 & \\
\hline L.S.D 5\% & 0.13 & & & & 0.13 & 0.24 & & & & 0.24 \\
\hline L.S.D 5\% & 0.27 & & & & & 0.49 & & & & \\
\hline
\end{tabular}

\section{REFERENCES}

[1] F.A.O., 2013. Food and Agriculture Organization of the Nation. Quarterly bulletin Statistics ,11(3/4).

[2] Tollenaar, M., M.W. Deen, L.E. Echart and W. Liu, 2003. Effect of crowding stress on dry matter accumulation and harvest index in maize. Agro. J. 98: 930937.

[3] Duvick, D.N., 2005. Genetic progress in yield of United States maize. Maydica, 50(3):193-202.

[4] Elsahookie, M.M., 2007. Dimensions of SCC theory in a maize hybrid-inbred comparison. The Iraqi J. Agric. Sci., 38(1):128-137.

[5] Tollenaar, M. and E.A. Lee, 2002. "Yield potential, yield stability and stress tolerance in maize." Field Crops Research, 75(2-3): 161-169.

[6] Elsahookie, M.M., 1980. Maize product and improve, Ministry of Higher Education and Scientific research. Baghdad University, pp: 399.

[7] Steel, R.G.D. and J.H. Torrie, 1980. Principles and Procedures, of Statistics. A biometrical approach.2nd ed. M, Graw Hill Book Co. NY. U.S.A., pp: 485.

[8] Abed, Z.A., 2008. Chlorophyll Content of Maize Hybrid and Inbred as Influenced by Level of Density and nitrogen. Ph.D. Dissertation. Dept. of Field Crop Sci. College of Agric. Univ. of Baghdad. Iraq, pp: 93.

[9] Bactash, F.Y., K.M. Wahib, 2004. Response of maize to levels of nitrogen fertilizer and plant densities. Journal of Iraqi Agricultural Sciences, 35(1): 85-96.

[10] Aziz, F.O.J., 2008. Breeding Sunflower, Sorghum and Maize by Honycomb. Ph.D. Thesis, Dept. of Field Crop Sci, Coll. of Agric, Univ. of Baghdad, pp: 4561.

[11] Tetiokalgho, F. and F.P. Gardener, 1988. Response of maize to plant population density. I. Canopy development, light relationships and vegetative growth. Agric. J., 80: 930-935.

[12] Potters, G., T.P. Pasternak, Y. Guisez, K.J. Palme and M.A. Jansen, 2007. Stress-induced morphogenic responses: growing out of trouble?. Trends in plant science, 12(3): 98-105.

[13] Hamdalla, M.S., 2006. The Relative Number of Favorable Genes and Some Criteria of Hybrid Vigor in Maize. Ph.D. Dissertation. Dept. of Field Crop Sci. Coll. of Agric. Baghdad University, pp: 115.

[14] Borras, L., M.E. Westgate, J.P. Astini and L. Echarte, 2007. Coupling time to silking with plant growth rate in maize. Field Crop Res., $102: 73-85$.

[15] Ma, G.S., J.Q. Xue, H.D. Lue, R.H. Zhang, S.J. Tai and J.H. Ren, 2007. Effect of planting data and density on population physiology indices of summer corn in central Shaanix irrigation area. Chinese J. App. Ecol., 18(6): 1247-11253.

[16] O'Neill, P.M., J.F. Shanahan, J.S. Scheper and B. Galdwell, 2004. Agronomic response of corn hybrid from different ears to deficient and adequate of water and nitrogen. Agron. J., 96: 1660-1667.

[17] Fahdawi, A.J.A., 2012. Effect of Potassium Fertilizer and Plant Density on the Growth and Distribution of Two cultivars of maize. Master Thesis. Department of Field Crops - College of Agriculture - Anbar University, pp: 102.

[18] Hadi, B.H., 2012. The response of maize to the criteria of selection under two levels of nitrogen. Ph.Dthesis., Field Crops Department, College of Agriculture, University of Baghdad, pp: 92.

[19] Al-Khazali, H.A., F.Y. Bektaash, 2013. Genetic variability of some characters of sorghum under plant densities of the crop and its components. Iraqi Agricultural Science, 44(4): 447-454.

[20] Haghighar, A., A.H.S. Rad, S. Seifzadeh, P. Zandi and M. Yousefi, 2011. Effect of plant density and cattle manure on some agronomic traits sweet corn under different culture methods. Aust. J. of Basic and Apple. Sci., 5(2): 2060-2075.

[21] Sharifi, R.S., M. Sedghi and A. Gholipouri, 2009. Effect of population density on yield and yield attributes of maize hybrids. Res. J. of Biological Sci., 4(4): 375-379. 